\title{
Phytoestrogens and Their Health Effect
}

\author{
Desmawati Desmawati , Delmi Sulastri \\ Department of Nutrition, Medical Faculty, Andalas University, Padang 25163, West Sumatera, Indonesia
}

\author{
Citation: Desmawati D, Sulastri D. Phytoestrogens and \\ their Health Effect. Open Access Maced J Med Sci. 2019 \\ https://doi.org/10.3889/oamjms.2019.086 \\ Keywords: Phytoestrogens; Phytochemicals; Health \\ ${ }^{\star}$ Correspondence: Desmawati Desmawati. Department \\ of Nutrition, Medical Faculty, Andalas University, Padang. \\ West Sumatera, Indonesia, 25163. E-mail \\ desmawati@med.unand.ac.id \\ Received: 09-Nov-2018; Revised: 31-Jan-2019; \\ Accepted: 01-Feb-2019; Online first: 14-Feb-2019 \\ Copyright: () 2019 Desmawati Desmawati, Delmi \\ Sulastri. This is an open-access article distributed under \\ the terms of the Creative Commons Attribution-
NonCommercial 4.0 International License (CC BY-NC 4.0) \\ Funding: This research did not receive any financial \\ support \\ Competing Interests: The authors have declared that no \\ Competing Interests: The
competing interests exist
}

\section{Introduction}

Phytoestrogens are estrogen-like compounds derived from plants, which are structurally similar to $17 \beta$-estradiol. Four phenolic compounds classified as phytoestrogens are isoflavones, stilbene, coumestan, and lignan [1], [2], [3], [4].

Isoflavones are found in soybeans and other legumes, including in red clover. The main phytoestrogens in the form of isoflavones are genistein, daidzein, glycitein, formononetin, and biochanin A contained in soybeans. Phytoestrogens that are classified as isoflavones are the most widely studied. The amount of isoflavones needed to give health effects is around $40-70 \mathrm{mg} /$ day or an average of $50 \mathrm{mg} /$ day. The average consumption of isoflavones in Asian society is $15-50 \mathrm{mg}$ per day, while in Western countries only about $2 \mathrm{mg}$ per day [5], [6].

The most common stilbene group is resveratrol, which is found in grapes and peanuts. Resveratrol consists of two isomers namely cis and trans. Trans has a higher estrogenic activity. Not all groups of comrades who have estrogenic activity. Contestants that have estrogenic activity come from nuts, broccoli, cabbage and spinach. The main sources of lignans are flaxseed, and also in wheat flour, peanuts, fruits, berries, vegetables, tea and coffee. One example of lignans is matairesinol (nonestrogenic dimer) which can be converted by intestinal microbes into enterolactone which is estrogenic and easily absorbed [1], [2], [3], [4].

The source of phytoestrogens are nuts, seeds, fruits and vegetables. Food sources include soybeans, garlic, celery, carrots, potatoes, rice, wheat, red clover, sweet potatoes, fruits (apples, pomegranates and chaste berries) and coffee [3], [4]. Isoflavones are found in legumes, especially soybeans. Flaxseeds are the main source of lignans, and many contestants are found in clover, alfalfa and soybean sprouts [1], [3]. Phytoestrogens in the diet are digested, then metabolised by bacteria in intestinal, absorbed in the intestinal and conjugated in the liver. Furthermore, the phytoestrogens circulate in the plasma until they are finally excreted in the urine [3].

The most important source of phytoestrogens is isoflavones found in soybeans and their processed products. Phytoestrogen levels in pure soybeans are higher than those that have been processed because of differences in bioavailability. Asian people consume 
more soy than Europeans and Americans [1], [7]. The average daily intake of community phytoestrogens in East and Southeast Asia is estimated to be between 20-50 mg per day. While the average intake of phytoestrogens in adults in the United States is only $0.15-3 \mathrm{mg}$ per day, and in Europe, it is much lower at around 0.49 to $0.66 \mathrm{mg}$ per day [1].

Bioavailability and pharmacokinetics of isoflavones are influenced by the texture of food ingredients the source or form of food consumed. Liquid food is absorbed faster and has a higher concentration in plasma than solid food. Isoflavones in the form of aglycones are absorbed more quickly than in the form of glucoside conjugates [7].

The isoflavones contained in soybeans are in the form of a complex mixture of glucoside conjugates. Then it is hydrolysed in the digestive tract by the intestinal mucosa with the help of bacteria $\beta$ glucosidase to be aglycon, genistein and daidzein. Anglican can be absorbed directly or metabolised by microflora in the large intestine into active metabolites in the form of equol and inactive metabolites in the form of O-desmethylangolensin (ODMA) 3 . Lignan is converted to secoisolaricisinol-diglucoside (SDG), and the constant is converted to coumestrol. The level of absorption and metabolism in the body [5], [7], [8]. The ability to convert phytoestrogens to equol is influenced by race. Japanese, Chinese and Korean can convert equol higher than the Western population which is estimated to produce only around $30-40 \%$. This is related to the role of genetics, the composition of intestinal microbiota and diet [9].

Phytoestrogens have structures that are very similar to endogen estradiol and be able to bind with alpha and beta receptors of estrogen [6], [10]. Alpha and beta estrogen receptors have different functions. Alpha estrogen receptors act in cell proliferation, whereas beta receptors are responsible for cell apoptosis [6]. After the receptor binds to the ligand, then moves from the cytoplasm to the cell nucleus, binding and influencing the area that controls the DNA transcription process or small RNA, which in turn affects the expression of certain genes [3], [6]. Therefore, phytoestrogens have the potential effects to regulated all process that influence by estrogen including the induction of sex hormones that bind to globulin and inhibit aromatase [3].

Endogenous estrogen levels also affect the activity of phytoestrogens. In women of reproductive age, endogenous estrogen levels in high blood pressure. In this condition, lignans will compete with endogenous estrogen to bind to estrogen receptors so that they can inhibit estrogen activity. But at menopause, endogenous estrogen levels are low in estrogen production by the ovaries. When estrogen levels are low, lignans are weak estrogen [4]. Isoflavones, lignans and proteins also function as aromatase inhibitors by inhibiting the action of cytochrome P450 enzymes that convert androgens to estrogen. Elevated levels of the cytochrome P450 enzyme are associated with breast, adrenal and prostate cancers [4].

Phytoestrogens also have biological effects without going through estrogen receptors. Phytoestrogens can activate serotoninergic receptors, insulin-like growth factor (IGF) receptors 1, free radical binding, induction of DNA methylation, affect tyrosine kinases, cycle adenosine monophosphate (CAMP), phosphatidylinositol-3 kinase/Akt and mitogen-activated protein (MAP) kinases, transcription of nuclear factor-kappa $\beta$ (NF-K $\beta$ ) factor, histone modification and RNA expression and act as an intracellular regulator in the cell cycle and apoptosis [6]. This ability causes phytoestrogens to have an antioxidant, antiproliferative, antimutagenic and antiangiogenic role and can improve health and longevity [3], [6], [11].

\section{Phytoestrogens and reproduction health}

Phytoestrogens have different effects on the reproductive process. Genistein can stimulate progesterone stimulation in the ovaries, production of estradiol and CAMP production, oocyte maturation and zygote development in the preimplantation stage. Phytoestrogens derived from the green and Indian turmeric can inhibit proliferation, increase apoptosis and affect steroid hormone release by animal ovarian cells. Isoflavones can also change animal sexual development, including changes in puberty, disruption of the oestrous cycle and ovarian function. Several studies suggest that there is an effect of isoflavones contained in infant formula milk on their reproductive development, although phytoestrogen side effects on reproductive health have not been widely reported [11], [12].

Phytoestrogens can also suppress the clinical symptoms of menopause caused by a decrease in the production of endogenous estrogen. Administration of $100 \mathrm{mg}$ of isoflavones per day in postmenopausal women can reduce vasomotor symptoms. The advantage of this phytoestrogen is that it does not hurt the breast and endometrium [3], [11], [13]. Also, phytoestrogens also do not increase the risk of clotting in postmenopausal women [5]. This causes phytoestrogens to be a safe alternative to hormone replacement therapy [4].

\section{Phytoestrogens and Cardiovascular disease}

Several studies have proven the protective effects of phytoestrogens on cardiovascular disease. Phytoestrogens can reduce total cholesterol and improve heart function. Genistein consumption of 200 $\mathrm{mg}$ per day can reduce total cholesterol [14]. Consumption of phytoestrogens derived from soy can affect plasma lipoprotein levels (lower LDL cholesterol 
and increase HDL cholesterol), reduce plasma triglyceride levels, inhibit oxidised LDL and lower blood pressure and C-reactive protein (CRP) [15]. Increased phytoestrogen intake results in lower serum total cholesterol and LDL levels, and in some cases leads to an increase in HDL levels [16].

Isoflavones can reduce hypertension through vasodilatation effects. Six months of isoflavone administration in postmenopausal women has been shown to increase endothelial vasodilation and reduce the number of cell adhesion molecules such as intracellular adhesion molecule 1, vascular cell adhesion protein 1 and E-selectin. Isoflavones can increase kidney blood flow, excretion of sodium, and inhibit the activity of angiotensin converting enzyme (ACE). However, the effect of decreasing blood pressure by isoflavones is more evident in patients with hypertension than normotension [17].

Phytoestrogens also affect blood sugar regulation. Research on Asian and non-Asian women found that phytoestrogens can reduce fasting blood sugar levels, circulating insulin and homeostatic model assessment for insulin resistance (HOMA-IR), but did not affect post prandial blood sugar levels and HbA1c [14].

It is also proven that the lower incidence of chronic diseases is found in East Asian people who consume soybeans containing isoflavones and their processed products. Contrary to Western populations who experience more chronic disease, it is thought that they consume fewer soy products [17], [18].

\section{Phytoestrogens and weight loss}

Another benefit of phytoestrogens is to lose weight. Phytoestrogens can increase fat-free mass and reduce fat accumulation by inhibiting the life cycle of adipocytes. Long-term isoflavone supplementation can also reduce visceral fat tissue and serum leptin concentration. Phytoestrogens also inhibit a moderate degree of inflammation that arises in obesity through its antioxidant effects [12], [14]. Some studies suggest that phytoestrogens, especially those from soy and its products, have a significant effect on weight loss, both in animal and in humans studies. A randomised controlled clinical trial by Allison conducted on 74 obese people stated that there was a significant weight loss after administration of soy-based meal replacement formula. This treatment was carried out in two groups (treatment and control groups) for 12 weeks. At the end of the study, we found a significant difference in weight loss between the two groups $(7.00 \mathrm{~kg}$ vs $2.90 \mathrm{~kg})$ [19]. Other studies in animals have shown the protective effect of phytoestrogens on the risk of obesity in estrogen-deficient mice. Administration of phytoestrogens in female albino rats which were ovariectomized affected the amount of intake and weight. In the group of mice given a diet high in phytoestrogens there was a decrease in the amount of food intake and increase weight loss significantly compared to the control group. This is caused by appetite suppression which is one of the effects of estrogen. Because phytoestrogens have a structure similar to estrogen and can bind to estrogen receptors, so, phytoestrogens also have appetite suppressing properties. It added again with a decrease in the amount of food intake to accelerate weight loss [20]. Also, the increase in fat loss can be attributed to the capability of phytoestrogens to induce the apoptosis of adipocytes, suggesting that at least part of the weight loss is ablation of fat cells [21].

\section{Phytoestrogens and hormone-dependent tumour}

The use of isoflavones since adolescence is associated with a reduced risk of breast cancer compared to hormone replacement therapy that can increase the risk of breast cancer in menopausal women. Phytoestrogens also have a protective effect on the risk of endometrial cancer [5]. This is related to the properties of phytoestrogens that can act as antioxidant, antimutagenic, antiangiogenic, proapoptotic and anti-cancer [12].

Estrogen or alpha or beta estrogen receptors depend on their concentration. To bind to the alpha estrogen receptor, estrogen must have a concentration 10 times higher than to bind to the estrogen receptor beta. Conversely, phytoestrogens can bind to beta receptors at lower concentrations than alpha estrogen receptors so that phytoestrogens can bind to both receptors at the same time. This is what causes the protective effects of phytoestrogens on breast cancer and endometrial cancer [6], [12].

A study conducted in mice found that administration of phytoestrogens for 8 weeks did not cause changes in the cause of pituitary precancerous growth or change in estrogen-sensitive organs such as the uterus, ovary, cervix, liver, and kidney. This is in contrast to external estrogen-induced effects (diethylstilbestrol/DES) which can be induced weight increase on the ovary and cervix, as well as gross structural changes that include decreases in tissue cell density, increases in vascularity, and multiple hemorrhagic areas. Although in this study it was found that administration of phytoestrogens has not been able to reduce the effects caused by DES, phytoestrogens can be used as an alternative to hormone replacement therapy [23].

\section{Phytoestrogens and bone health}

The results of research on the effects of phytoestrogens on bone health are still not consistent. Some studies say that there is no relationship between phytoestrogen intake and bone health. A meta-analysis of randomised clinical trials in humans found a weak link between increased intake of soy 
isoflavones and increased bone mineral density [24]. Other studies also state that there are bone sharing benefits from the consumption of phytoestrogens. The daily consumption of $200 \mathrm{mg} / \mathrm{kg}$ phytoestrogens in OVX rats for 8 weeks increases the concentration of femoral calcium but also increases the weight of the uterus. Likewise with the administration of isoflavones-rich soy milk for 2 years can increase $2.4 \%$ of bone mineral density in older women [25].

Also, the administration of phytoestrogens combined with vitamin $D$ in aged ovariectomized female rats also increases bone mineral density. Vitamin D was given as $2,400 \mathrm{IU} / \mathrm{kg}$ singly or in combination with various types of phytoestrogens (resveratrol, quercetin, and genistein) with multilevel doses. The results of this study prove that the combination of phytoestrogens with vitamin $D$ has synergistic effects and may be effective in reducing bone loss after menopause [26]. This increase in bone mineral density may be caused by the consumption of phytoestrogens which can increase osteoblast synthesis and reduce bone resorption, but this positive effect is obtained from long-term consumption of phytoestrogens, at least six months [5]. So, the effect of phytoestrogens on bone health is influenced by the dose, duration, and age of the subject. For many women, adding soy to an already healthful diet may be an option to help stave off bone loss in midlife [5], [27].

\section{Phytoestrogens and cognitive function}

The interaction of phytoestrogens with estrogen receptors is also a positive influence on cognitive function. Phytoestrogens as neuroprotectors and antioxidants can reduce the risk of Alzheimer's disease [28]. Phytoestrogens affect the workings of the nervous system via steroid receptors and 5hydroxytryptamine receptors or by increasing serotonin reuptake. Also, it also can influence the synthesis and uptake of catecholamines through estrogen receptors in the plasma membrane [12].

\section{Phytoestrogens and skin health}

Phytoestrogens can act as antiaging in the skin through estrogen receptors or increased production of hyaluronic acid, collagen, and extracellular protein matrix. Also, phytoestrogens can also increase vascularisation of skin, proliferation, prevent skin from oxidative stress and apoptosis. Ageing of the skin can be inhibited by the administration of phytoestrogens [3].

The protective effects of phytoestrogens on skin health can occur through several mechanisms. It can reduce UV-induced cell death in cultured keratinocytes, improve skin elasticity, increase the depth and increase the production of type 1 procollagen. It offers protection against UV induced senescence by significantly upregulating intracellular SOD activity in a dose-dependent manner. Phytoestrogens also have potent antioxidant effects with strong anti-inflammatory properties [29]. Other studies also proved that the provision of concentrated, isoflavone-rich soy extract during the six consecutive months caused significant increases in epithelial thickness, the number of elastic and collagen fibres, as well as the blood vessels. This study was conducted on 30 postmenopausal women before and immediately after treatment with $100 \mathrm{mg} /$ day of isoflavones-rich, concentrated soy extract for six months [30].

\section{Phytoestrogens and the immune system}

Phytoestrogens affect the immune system through its ability to inhibit intracellular signalling pathways associated with NF-kappaB and immune responses. Genistein can suppress specific immune responses and lymphocyte proliferation [12].

Phytoestrogens suppress the immune response in vivo and in vitro. Phytoestrogens can suppress specific immune responses and suppress lymphocyte proliferation. Also, genistein can inhibit an allergic inflammatory response. Genistein can increase cytokine production from $\mathrm{T}$ cells and enhance cytotoxic responses mediated by natural killers and cytotoxic T cells [31].

A study in mice that gave $8-80 \mathrm{mg} / \mathrm{kg}$ of genistein over 28 days found that there were $46-67 \%$ decreases in the delayed-type hypersensitivity response, and these effects were reversible. Its also found that there was a decrease in cell infiltration in genetically treated animals compared with controls, and the numbers of CD4 + and CD8 + T cells in normal lymph nodes were reduced on histopathological examination. This study concluded that Dietary genistein (1000 or $1500 \mathrm{ppm}$ ) decreased cell-mediated immunity while producing serum genetic concentrations for humans under certain nutritional conditions [32]. However, the mechanism of action of phytoestrogens for the immune system needs to be studied further.

In conclusion, phytoestrogens have many positive benefits for the health of various organs. Many sources of phytoestrogens are also spread in the world which can be used as an alternative to external estrogen substitutes or hormone replacement therapy.

\section{Acknowledgements}

Authors are thankful to the Medical Faculty of Andalas University for their encouragement, 
motivation towards publication and research atmosphere during the recent literature search and future's planned research study.

\section{References}

1. Sirtori CR, Arnoldi A, Johnson SK. Phytoestrogens: end of a tale? Annals of medicine. $2005 ; 37(6): 423-38$.

https://doi.org/10.1080/07853890510044586 PMid:16203615

2. Cornwell T, Cohick W, Raskin I. Dietary phytoestrogens and health. Phytochemistry. 2004; 65(8):995-1016.

https://doi.org/10.1016/j.phytochem.2004.03.005 PMid:15110680

3. Sirotkin AV, Harrath AH. Phytoestrogens and their effects. European journal of pharmacology. 2014; 741:230-6.

https://doi.org/10.1016/i.ejphar.2014.07.057 PMid:25160742

4. Poluzzi E, Piccinni C, Raschi E, Rampa A, Recanatini M, De Ponti F. Phytoestrogens in postmenopause: the state of the art from a chemical, pharmacological and regulatory perspective. Current medicinal chemistry. 2014; 21(4):417-36. https://doi.org/10.2174/09298673113206660297 PMid:24164197 PMCid:PMC3963458

5. Bedell S, Nachtigall M, Naftolin F. The pros and cons of plant estrogens for menopause. The Journal of steroid biochemistry and molecular biology. 2014; 139:225-36. https://doi.org/10.1016/.j.jsbmb.2012.12.004 PMid:23270754

6. Rietjens IM, Sotoca AM, Vervoort J, Louisse J. Mechanisms underlying the dualistic mode of action of major soy isoflavones in relation to cell proliferation and cancer risks. Molecular nutrition \& food research. 2013; 57(1):100-13. https://doi.org/10.1002/mnfr.201200439 PMid:23175102

7. Cassidy A, Brown JE, Hawdon A, Faughnan MS, King LJ, Millward J, et al. Factors affecting the bioavailability of soy isoflavones in humans after ingestion of physiologically relevant levels from different soy foods. The Journal of nutrition. 2006; 136(1):45-51. https://doi.org/10.1093/in/136.1.45 PMid:16365057

8. Setchell KD, Brown NM, Lydeking-Olsen E. The clinical importance of the metabolite equol-a clue to the effectiveness of soy and its isoflavones. The Journal of nutrition. 2002; 132(12):3577-84

https://doi.org/10.1093/in/132.12.3577 PMid:1246859

9. Vedrine N, Mathey J, Morand C, Brandolini M, Davicco M, Guy L, et al. One-month exposure to soy isoflavones did not induce the ability to produce equol in postmenopausal women. European journal of clinical nutrition. 2006; 60(9):1039-45. https://doi.org/10.1038/sj.ejcn.1602415 PMid:16482068

10. Paterni I, Granchi C, Katzenellenbogen JA, Minutolo F. Estrogen receptors alpha $(E R \alpha)$ and beta $(E R \beta)$ : subtype-selective ligands and clinical potential. Steroids. 2014; 90:13-29.

https://doi.org/10.1016/i.steroids.2014.06.012 PMid:24971815 PMCid:PMC4192010

11. Cederroth CR, Zimmermann C, Nef S. Soy, phytoestrogens and their impact on reproductive health. Molecular and cellular endocrinology. 2012; 355(2):192-200. https://doi.org/10.1016/i.mce.2011.05.049 PMid:22210487

12. Jefferson WN, Williams CJ. Circulating levels of genistein in the neonate, apart from dose and route, predict future adverse female reproductive outcomes. Reproductive Toxicology. 2011; 31(3):272-9. https://doi.org/10.1016/j.reprotox.2010.10.001 PMid:20955782 PMCid:PMC3192433

13. Teekachunhatean S, NatnitaMattawanon, Khunamornpong S. ShortTerm Isoflavone Intervention in the Treatment of Severe Vasomotor Symptoms after Surgical Menopause: A Case Report and Literature Review. Case Reports in Obstetrics and Gynecology. 2015. https://doi.org/10.1155/2015/962740 PMid:26605099 PMCid:PMC4641951

14. Legette LL, Lee W-H, Martin BR, Story JA, Arabshahi A, Barnes S, et al. Genistein, a phytoestrogen, improves total cholesterol and Synergy ${ }^{\circledR}$, a prebiotic, improved calcium utilization but there were no synergistic effects. Menopause (New York, NY). 2011; 18(8):923.

https://doi.org/10.1097/gme.0b013e3182116e81 PMid:21659907 PMCid:PMC3181048
15. Anthony MS. Phytoestrogens and Cardiovascular Disease. Am Heart Assoc; 2002; Liu Z-m, Ho SC, Chen Y-m, Liu J, Woo J. Cardiovascular risks in relation to daidzein metabolizing phenotypes among Chinese postmenopausal women. Plos one. 2014; 9(2):e87861.

16. Nagamma T, Jagadeesh AT, Bhat KM. Effect of Phytoestrogens on Lipid Profile: Mini Review. Asian J Pharm Clin Res. 2017; 10(2):50-3. https://doi.org/10.22159/ajpcr.2017.v10i2.15684

17. Ramdath DD, Padhi EM, Sarfaraz S, Renwick S, Duncan AM. Beyond the Cholesterol-Lowering Effect of Soy Protein: A Review of the Effects of Dietary Soy and Its Constituents on Risk Factors for Cardiovascular Disease. Nutrients. 2017; 9(4):324. https://doi.org/10.3390/nu9040324 PMid:28338639 PMCid:PMC5409663

18. Reinwald S, Akabas SR, Weaver CM. Whole versus the piecemeal approach to evaluating soy. The Journal of nutrition. 2010; 140(12):2335S43S. https://doi.org/10.3945/in.110.124925 PMid:20980652

19. Allison DB, Gadbury G, Schwartz LG, Murugesan R, Kraker JL, Heshka $S$, et al. A novel soy-based meal replacement formula for weight loss among obese individuals: a randomized controlled clinical trial. European journal of clinical nutrition. 2003; 57(4):514. https://doi.org/10.1038/sj.ejcn.1601587 PMid:12700612

20. Tolba EA-EHT. Dietary phytoestrogens reduce the leptin level in ovariectomized female rats. Cellulose. 2013; 1(1.10):0.17.

21. Kim S, Sohn I, Lee YS, Lee YS. Hepatic gene expression profiles are altered by genistein supplementation in mice with diet-induced obesity. The Journal of nutrition. 2005; 135(1):33-41. https://doi.org/10.1093/jn/135.1.33 PMid:15623829

22. Rietjens IM, Louisse J, Beekmann K. The potential health effects of dietary phytoestrogens. British journal of pharmacology. 2016. PMid:27723080 PMCid:PMC5429336

23. Jeng Y-J, Kochukov M, Nauduri D, Kaphalia BS, Watson CS. Subchronic exposure to phytoestrogens alone and in combination with diethylstilbestrolpituitary tumor induction in Fischer 344 rats. Nutrition \& metabolism. 2010 7(1):40. https://doi.org/10.1186/1743-7075-7-40 PMid:20459739 PMCid:PMC2881934

24. Liu J, Ho SC, Su Y-x, Chen W-q, Zhang C-x, Chen Y-m. Effect of long term intervention of soy isoflavones on bone mineral density in women: a meta-analysis of randomized controlled trials. Bone. 2009; 44(5):948-53. https://doi.org/10.1016/j.bone.2008.12.020 PMid:19168161

25. Legette LL, Martin BR, Shahnazari M, Lee W-H, Helferich WG, Qian J, et al. Supplemental dietary racemic equol has modest benefits to bone but has mild uterotropic activity in ovariectomized rats. The Journal of nutrition. 2009; 139(10):1908-13. https://doi.org/10.3945/jn.109.108225 PMid:19710157 PMCid:PMC274461

26. Lai C-Y, Yang J-Y, Rayalam S, Della-Fera MA, Ambati S, Lewis RD, et al. Preventing bone loss and weight gain with combinations of vitamin $\mathrm{D}$ and phytochemicals. Journal of medicinal food. 2011; 14(11):1352-62. https://doi.org/10.1089/jmf.2010.0232 PMid:21663481

27. Ming LG, Chen KM, Xian CJ. Functions and action mechanisms of flavonoids genistein and icariin in regulating bone remodeling. Journal of cellular physiology. 2013; 228(3):513-21. https://doi.org/10.1002/icp.24158 PMid:22777826

28. Soni M, Rahardjo TBW, Soekardi R, Sulistyowati Y, Lestariningsih, Yesufu-Udechuku A, et al. Phytoestrogens and cognitive function: a review. Maturitas. 2014; 77:209 - 20. https://doi.org/10.1016/j.maturitas.2013.12.010 PMid:24486046

29. Thornton MJ. Estrogens and aging skin. Dermato-endocrinology. 2013; 5(2):264-70. https://doi.org/10.4161/derm.23872 PMid:24194966 PMCid:PMC3772914

30. Accorsi-Neto A, Haidar M, Simões R, Simões M, Soares-Jr J, Baracat E. Effects of isoflavones on the skin of postmenopausal women: a pilot study. Clinics. 2009; 64(6):505-10. https://doi.org/10.1590/S180759322009000600004 PMid:19578653 PMCid:PMC2705153

31. Chiang S-S, Pan T-M. Beneficial effects of phytoestrogens and their metabolites produced by intestinal microflora on bone health. Applied microbiology and biotechnology. 2013; 97(4):1489-500. https://doi.org/10.1007/s00253-012-4675-y PMid:23318837

32. Yellayi S, Zakroczymski M, Selvaraj V, Valli V, Ghanta V, Helferich W, et al. The phytoestrogen genistein suppresses cell-mediated immunity in mice. Journal of endocrinology. 2003; 176(2):267-74

https://doi.org/10.1677/joe.0.1760267 PMid:12553875 